\title{
Salinicoccus albus sp. nov., a halophilic bacterium from a salt mine
}

\author{
Correspondence \\ Xiao-Long Cui \\ xlcuiynu@yahoo.com.cn \\ or \\ xlcui@ynu.edu.cn
}

\author{
Yi-Guang Chen, ${ }^{1,2}$ Xiao-Long Cui, ${ }^{1}$ Yong-Xia Wang, ${ }^{1}$ Yu-Qin Zhang, ${ }^{1,3}$ \\ Qin-Yuan Li, ${ }^{4}$ Zhu-Xiang Liu, ${ }^{2}$ Meng-Liang Wen, ${ }^{1}$ Qian Peng ${ }^{1}$ \\ and Wen-Jun $\mathrm{Li}^{1}$
}

\author{
${ }^{1}$ Yunnan Institute of Microbiology, Yunnan University, Kunming, Yunnan 650091, PR China \\ ${ }^{2}$ College of Bio-resources and Environmental Science, Jishou University, Jishou, Hunan 416000, \\ PR China
${ }^{3}$ Institute of Medicinal Biotechnology, Chinese Academy of Medical Sciences and Peking Union Medical College, Beijing 100050, PR China \\ ${ }^{4}$ Experiment Center of Life Sciences, Yunnan University, Kunming, Yunnan 650091, PR China
}

The genus Salinicoccus was proposed by Ventosa et al. (1990), and was defined as containing Gram-positive, catalase- and oxidase-positive, non-motile, non-sporeforming cocci, with MK-6 as the predominant respiratory quinone and a cell-wall peptidoglycan type of L-Lys-Gly . At the time of writing, the genus comprised nine species with validly published names: Salinicoccus roseus and S. hispanicus (Ventosa et al., 1990, 1992), S. alkaliphilus (Zhang et al., 2002), S. salsiraiae (Franca et al., 2006), S. jeotgali (Aslam et al., 2007), S. luteus (Zhang et al., 2007), S. siamensis (Pakdeeto et al., 2007), S. kunmingensis (Chen et al., 2007a) and S. iranensis (Amoozegar et al., 2008). In a

The GenBank/EMBL/DDBJ accession number for the 16S rRNA gene sequence of strain $\mathrm{YIM}-\mathrm{Y} 21^{\top}$ is EF177692.

A supplementary table of the fatty acid compositions of strain $\mathrm{YIM}-\mathrm{Y} 21^{\top}$ and other members of the genus Salinicoccus is available with the online version of this paper. recent study of the microbial diversity in the ancient salt deposit of the Yipinglang salt mine $\left(25^{\circ} 18^{\prime} \mathrm{N} 101^{\circ} 54^{\prime} \mathrm{E}\right)$ in Yunnan, south-west China (Chen et al., 2007a, b), a moderately halophilic, facultatively alkaliphilic strain, YIM-Y $21^{\mathrm{T}}$, was isolated from a subterranean brine sample. Polyphasic taxonomic study of the phenotypic, chemotaxonomic and phylogenetic position of strain YIM-Y $21^{\mathrm{T}}$ indicate that this strain is a representative of a novel species of the genus Salinicoccus.

A brine sample (salt-saturated, $\mathrm{pH}$ 6.8) was collected from the Yipinglang salt mine at a depth of about $200 \mathrm{~m}$. Serial $1: 10$ dilutions of the sample were plated on Difco marine agar 2216 (MA; pH 7.5) supplemented with 0-30.0\% NaCl at $28{ }^{\circ} \mathrm{C}$ for $7-28$ days. A white colony was picked from a plate of MA supplemented with $10.0 \% \mathrm{NaCl}$ (MA10). After primary isolation and purification, the isolate, named strain YIM-Y $21^{\mathrm{T}}$, was preserved both on MA10 slants at $4{ }^{\circ} \mathrm{C}$ and in Difco marine broth 2216 (MB) supplemented 
with $20 \%$ glycerol at $-80{ }^{\circ} \mathrm{C}$. The reference strain $S$. kunmingensis YIM $\mathrm{Y}^{2} 5^{\mathrm{T}}$, which was employed as a control in phenotypic tests, was obtained from the collection of the Yunnan Institute of Microbiology. Unless otherwise indicated, morphological and physiological studies were performed with cells grown on MA10 $(\mathrm{pH} 8.5)$ at $25^{\circ} \mathrm{C}$. Cell morphology was examined with a light microscope (BH 2; Olympus) as well as with a transmission electron microscope (H-800; Hitachi). Gram staining was carried out by using the standard Gram reaction (Doetsch, 1981) combined with the $\mathrm{KOH}$ lysis test (Gregersen, 1978). Growth was tested at various temperatures $\left(5-55{ }^{\circ} \mathrm{C}\right.$, in increments of $5{ }^{\circ} \mathrm{C}$ ) on MA10 and at different $\mathrm{pH}$ values (5.0-11.0, in increments of $0.5 \mathrm{pH}$ units) on MA10 as well as in $\mathrm{MB}$ supplemented with $10.0 \% \mathrm{NaCl}$. For $\mathrm{pH}$ endurance experiments, the following buffer systems were used: $\mathrm{pH} 5.0,0.1 \mathrm{M}$ citric acid/0.1 M sodium citrate; pH 6.0-8.0, 0.1 M KH $\mathrm{KH}_{2} \mathrm{PO}_{4} / 0.1 \mathrm{M} \mathrm{NaOH}$; pH 9.0-10.0, $0.1 \mathrm{M} \quad \mathrm{NaHCO}_{3} / 0.1 \mathrm{M} \quad \mathrm{Na}_{2} \mathrm{CO}_{3} ; \quad \mathrm{pH} 11.0, \quad 0.1 \mathrm{M}$ $\mathrm{Na}_{2} \mathrm{HPO}_{4} / 0.1 \mathrm{M} \mathrm{NaOH}$. Tolerance of and requirement for salts were determined in nutrient broth (Difco) (NB; $3.0 \mathrm{~g}$ beef extract and $5.0 \mathrm{~g}$ peptone $\mathrm{l}^{-1}$ ) at various concentrations of $\mathrm{NaCl}, \mathrm{MgCl}_{2} \cdot 6 \mathrm{H}_{2} \mathrm{O}$ or $\mathrm{KCl}(0.5 \%$ and $1.0-33.0 \%$ in increments of $1.0 \%$ ) supplemented with modified artificial seawater [containing $\left(1^{-1}\right) \quad 5.94 \mathrm{~g}$ $\mathrm{MgSO}_{4} .7 \mathrm{H}_{2} \mathrm{O}, 4.53 \mathrm{~g} \mathrm{MgCl}_{2} .6 \mathrm{H}_{2} \mathrm{O}, 0.64 \mathrm{~g} \mathrm{KCl}$ and $1.3 \mathrm{~g} \mathrm{CaCl}_{2}$ ] (Lim et al., 2005), with trypticase soy agar (TSA; Difco) and ISP medium 2 agar (Shirling \& Gottlieb, 1966) as controls. Methyl red and Voges-Proskauer tests and determination of aesculin hydrolysis, indole and $\mathrm{H}_{2} \mathrm{~S}$ production, and nitrate and nitrite reduction were performed as recommended by Smibert \& Krieg (1994). Hydrolysis of casein, DNA, gelatin, starch, Tweens 20, 40, 60 and 80 and urease activity were determined as described by Cowan \& Steel (1965). Observation of motility and tests for antibiotic susceptibility, anaerobic growth and catalase and oxidase activities were performed as described by Chen et al. (2007a). Other enzyme activities were assayed by using API ZYM strips (bioMérieux) according to the manufacturer's instructions. Acid production from carbohydrates and utilization of carbon and nitrogen sources were determined as recommended by Ventosa et al. (1982), as well as by employing the API $50 \mathrm{CH}$ system (bioMérieux) and GP2 MicroPlates (Biolog) according to the manufacturers' instructions. All suspension media were supplemented with $10.0 \% \mathrm{NaCl}$ and artificial seawater and incubated at $25{ }^{\circ} \mathrm{C}$. The results of the phenotypic tests are given in the species description and in Table 1 .

DNA was isolated according to Hopwood et al. (1985) and the $\mathrm{G}+\mathrm{C}$ content was determined by using the HPLC method (Mesbah et al., 1989). Genomic DNA extraction, PCR-mediated amplification of 16S rRNA gene and purification of PCR products were done as described previously (Cui et al., 2001). Phylogenetic analysis was performed by using the software package MEGA version 3.1 (Kumar et al., 2004) after multiple alignment of sequence data with CLUSTAL x (Thompson et al., 1997). Distances (corrected by Kimura's two-parameter model; Kimura, 1980) were calculated and clustering was performed with the neighbour-joining method (Saitou \& Nei, 1987). Maximum-likelihood (Felsenstein, 1981) and parsimony (Kluge \& Farris, 1969) trees (not shown) were generated by using the algorithms contained in the PHYLIP package (Felsenstein, 2002). Bootstrap analysis was used to evaluate the tree topology of the neighbour-joining data by means of 1000 resamplings (Felsenstein, 1985).

The DNA G+C content of strain YIM-Y21 ${ }^{\mathrm{T}}$ was $46.1 \mathrm{~mol} \%$. The almost-complete $16 \mathrm{~S}$ rRNA gene sequence (1478 bp) of the strain was determined. Phylogenetic analysis based on 16S rRNA gene sequences revealed that the novel isolate belonged to the family Staphylococcaceae and was closely related to the type strains of the nine recognized species of the genus Salinicoccus (Ventosa et al., 1990). The ten sequences formed a distinct cluster in the phylogenetic tree, in which strain YIM-Y $21^{\mathrm{T}}$ occupied a distinct sub-branch at the periphery of the cluster, supported by a significant bootstrap resampling value (99\%) (Fig. 1). The values of sequence similarity between the isolate and the type strains of members of the genus Salinicoccus were in the range of $90.6 \%$ (S. iranensis $\mathrm{QW6}^{\mathrm{T}}$ ) to $93.8 \%$ (S. kunmingensis YIM $\mathrm{Y}^{\mathrm{T}}{ }^{\mathrm{T}}$ ). Species of the genus Jeotgalicoccus (Yoon et al., 2003; Hoyles et al., 2004) were the next closest relatives, but they formed a quite separate and robust cluster (Fig. 1). It is therefore evident from the phylogenetic data that strain YIM-Y $21^{\mathrm{T}}$ could be a representative of a previously unknown species of the genus Salinicoccus.

Isolation of the cell-wall fraction and preparation of the cell-wall hydrolysate were carried out by using the method of Schleifer (1985). The amino acid composition of the cell-wall hydrolysate was determined using TLC as described by Staneck \& Roberts (1974). Polar lipids were extracted by the method of Minnikin et al. (1979) and identified by separating with 2D TLC and spraying the chromatogram with specific reagents (Collins \& Jones, 1980). Isoprenoid quinones were analysed by HPLC as described by Groth et al. (1996). The fatty acid composition was determined as described by Sasser (1990) using the Microbial Identification System (MIDI; Microbial ID) with cells grown in $\mathrm{MB}$ supplemented with $10.0 \% \mathrm{NaCl}$ ( $\mathrm{pH} 8.5)$ in flasks on a rotary shaker at 200 r.p.m. and $25{ }^{\circ} \mathrm{C}$ for 3 days. The chemotaxonomic data for strain YIM-Y $21^{\mathrm{T}}$ were compatible with its assignment to the genus Salinicoccus. The major amino acid constituents of the cell-wall hydrolysate were glycine and lysine, which are compatible with the peptidoglycan type of L-Lys-Gly described for this genus (Ventosa et al., 1990). The fatty acid profile of strain YIM-Y $21^{\mathrm{T}}$ was similar to those of the type strains of the genus Salinicoccus (Supplementary Table S1, available in IJSEM Online). Major fatty acids of this strain were anteiso- $\mathrm{C}_{15: 0}(42.6 \%)$, anteiso- $\mathrm{C}_{17: 0}(15.4 \%)$ and iso- $\mathrm{C}_{15: 0}(13.7 \%)$. Menaquinone 6 (MK-6) $(69.2 \%)$ and MK-7 (30.8\%) were the respiratory quinones. The polar lipids of the strain consisted of diphosphatidylgly- 
Table 1. Differentiating characteristics of strain $\mathrm{YIM}-\mathrm{Y} 21^{\top}$ and the type strains of other Salinicoccus species

Strains: 1, YIM-Y21 ${ }^{\mathrm{T}}$ (data from this study); 2, S. kunmingensis YIM Y15 ${ }^{\mathrm{T}}$ (Chen et al., 2007a); 3, S. alkaliphilus T8 ${ }^{\mathrm{T}}$ (unless indicated, data from Zhang et al., 2002); 4, S. roseus DSM 5351 ${ }^{\mathrm{T}}$ (Ventosa et al., 1990); 5, S. hispanicus DSM 5352 (Marquez et al., 1990; Ventosa et al., 1992); 6, S. jeotgali S2R53-5 ${ }^{\mathrm{T}}$ (Aslam et al., 2007); 7, S. salsiraiae RH1 ${ }^{\mathrm{T}}$ (Franca et al., 2006); 8, S. siamensis PN1-2 ${ }^{\mathrm{T}}$ (Pakdeeto et al., 2007); 9, S. luteus YIM $70202^{\mathrm{T}}$ (Zhang et al., 2007); 10, S. iranensis QW6 ${ }^{\mathrm{T}}$ (Amoozegar et al., 2008). +, Positive; -, negative; tr, trace amount; ND, no data available. All strains possess MK-6 as the predominant respiratory quinone.

\begin{tabular}{|c|c|c|c|c|c|c|c|c|c|c|}
\hline Characteristic & 1 & 2 & 3 & 4 & 5 & 6 & 7 & 8 & 9 & 10 \\
\hline Colony colour & White & Yellow & Pinkish & Pink-red & Reddish orange & Orange & Pink-red & Orange & Orange & Orange-pink \\
\hline \multicolumn{11}{|l|}{ Growth temperature $\left({ }^{\circ} \mathrm{C}\right)$} \\
\hline Range & $5-40$ & $4-45$ & $10-49$ & $15-37$ & $15-40$ & $20-30$ & $20-45$ & $15-45$ & $4-45$ & $5.0-45.0$ \\
\hline Optimum & 25 & 37 & 32 & 37 & 37 & 30 & 37 & 37 & 30 & 35 \\
\hline \multicolumn{11}{|l|}{ Growth in $\mathrm{NaCl}(\%)$} \\
\hline Range & $1.0-30.0$ & $0.5-25$ & $0-25$ & $0.5-25$ & $0.9-25$ & $0.5-15$ & $0-22$ & $1.5-25$ & $1-25$ & $1.0-25.0$ \\
\hline Optimum & 10 & $8-10$ & 10 & 10 & 10 & 5 & 4 & 10 & 10 & $7.5-10.0$ \\
\hline \multicolumn{11}{|l|}{ Growth pH } \\
\hline Range & $6.0-10.0$ & $6.0-10.0$ & $6.5-11.5$ & $5.0-9.0$ & $6.0-9.0$ & $6.5-11.0$ & $6.5-9.5$ & $6-9$ & $7.0-11.0$ & $6.5-10$ \\
\hline Optimum & 8.5 & 8.0 & 9.5 & 7.5 & 8.0 & 7.0 & 8.0 & 8.5 & $8.0-9.0$ & 7.5 \\
\hline \multicolumn{11}{|l|}{ Hydrolysis of: } \\
\hline Aesculin & - & + & $+^{*}$ & - & + & + & - & - & + & - \\
\hline Casein & - & - & - & + & - & - & + & - & - & - \\
\hline Gelatin & - & - & - & + & + & - & + & - & - & - \\
\hline Starch & - & + & - & + & - & - & - & - & - & - \\
\hline Tween 80 & + & + & - & + & - & - & ND & - & - & - \\
\hline Nitrate reduced to nitrite & + & + & + & + & + & + & + & - & + & + \\
\hline Indole production & - & - & - & - & - & + & - & - & - & + \\
\hline Methyl red test & - & - & - & - & + & + & - & - & - & - \\
\hline Urease & - & - & + & - & + & - & - & - & - & - \\
\hline Voges-Proskauer test & + & - & - & - & - & - & - & - & - & - \\
\hline \multicolumn{11}{|l|}{ Acid production from: } \\
\hline D-Fructose & + & + & - & - & + & + & + & + & - & + \\
\hline D-Galactose & - & - & - & - & + & - & - & - & - & - \\
\hline D-Glucose & + & - & + & - & + & + & + & + & + & + \\
\hline Glycerol & - & - & - & - & + & + & + & + & $\mathrm{ND}$ & - \\
\hline Maltose & - & - & - & - & + & + & + & - & + & - \\
\hline D-Mannitol & + & + & + & - & + & - & - & - & $\mathrm{ND}$ & + \\
\hline Sucrose & - & + & - & - & + & - & - & - & + & - \\
\hline Presence of MK-7 (\%)† & 30.8 & 1.2 & - & $0.8^{*}$ & $\operatorname{tr}^{*}$ & $\operatorname{tr}$ & ND & ND & + & $\operatorname{tr}$ \\
\hline $\begin{array}{l}\text { DNA G + C content } \\
(\mathrm{mol} \%)\end{array}$ & 46.1 & 46.2 & 49.6 & 51.2 & 45.7 & 47.0 & 46.2 & 46.0 & 49.7 & 46.2 \\
\hline
\end{tabular}

${ }^{*}$ Data from Chen et al. $(2007 \mathrm{a})$.

$\dagger$ Percentages of total respiratory quinones are given where available.

cerol, phosphatidylglycerol and an unidentified phospholipid.

The results of phylogenetic analysis and chemotaxonomic studies supported the view that strain YIM-Y $21^{\mathrm{T}}$ should be assigned to the genus Salinicoccus. However, the white colony colour of strain YIM-Y $21^{\mathrm{T}}$, the strain's ability to tolerate up to $30.0 \% \mathrm{NaCl}$ and the comparatively low optimum temperature $\left(25{ }^{\circ} \mathrm{C}\right)$ for growth, as well as the positive result of Voges-Proskauer test, the significant amount of MK-7 (Table 1) and the high 16S rRNA gene sequence divergence (more than 6\%) from those of the other members of the genus, differentiated strain $\mathrm{YIM}-\mathrm{Y} 21^{\mathrm{T}}$ markedly from the type strains of the nine recognized Salinicoccus species. In conclusion, phylogenetic analysis based on 16S rRNA gene sequence data, its phenotypic distinctiveness and the chemotaxonomic data suggest that strain $\mathrm{YIM}-\mathrm{Y} 21^{\mathrm{T}}$ represents a novel species of the genus Salinicoccus, for which the name Salinicoccus albus sp. nov. is proposed.

\section{Description of Salinicoccus albus sp. nov.}

Salinicoccus albus (al'bus. L. masc. adj. albus white, referring to the colony colour).

Cells stain Gram-positive and are non-motile, nonsporulating, obligately aerobic cocci $(0.6-1.1 \mu \mathrm{m})$ that occur singly or in pairs, tetrads or clumps. Colonies are 


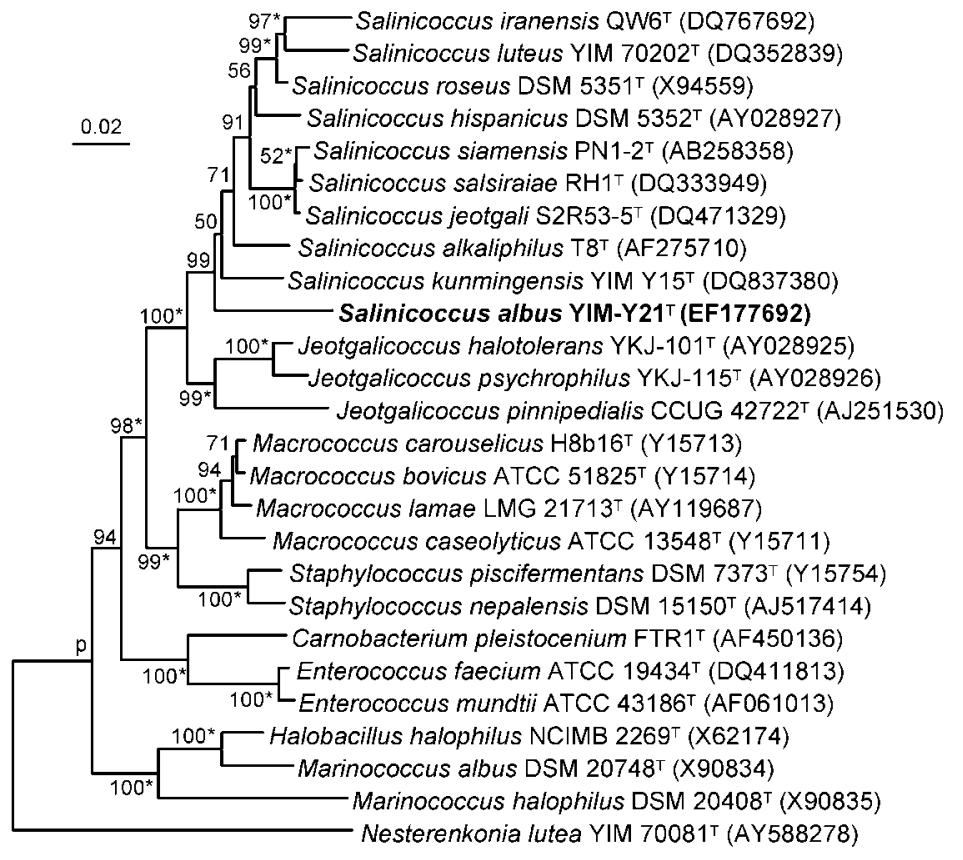

Fig. 1. Phylogenetic tree based on $16 \mathrm{~S}$ rRNA gene sequence analysis and constructed using the neighbour-joining method showing the phylogenetic positions of strains $\mathrm{YIM}-\mathrm{Y} 21^{\top}$ and related taxa. $p$, Branches that were also recovered with the maximum-parsimony (Kluge \& Farris, 1969) algorithm; *, branches that were also recovered using the maximumlikelihood (Felsenstein, 1981) and parsimony algorithms. Numbers at nodes indicate bootstrap values $(\geqslant 50 \%)$ based on neighbourjoining analysis of 1000 resampled datasets. Bar, 2 substitutions per 100 nt. white, circular, convex, smooth, non-translucent with entire margins, $1-2 \mathrm{~mm}$ in diameter after incubation at $25{ }^{\circ} \mathrm{C}$ for 3-5 days on MA supplemented with $10.0 \%$ $\mathrm{NaCl}$. No diffusible pigments are produced. Moderately halophilic and facultatively alkaliphilic, growth occurring with $1.0-30.0 \% \mathrm{NaCl}$ (optimum, $10.0 \% \mathrm{NaCl}$ ) and at $\mathrm{pH}$ 6.0-10.0 (optimum, $\mathrm{pH} 8.5$ ). $\mathrm{NaCl}$ cannot be replaced by $\mathrm{MgCl}_{2} \cdot 6 \mathrm{H}_{2} \mathrm{O}$ or $\mathrm{KCl}$. Growth at $5-40{ }^{\circ} \mathrm{C}$, with optimum growth at $25{ }^{\circ} \mathrm{C}$. Positive for hydrolysis of Tweens 40 and 80, but negative for hydrolysis of casein, DNA, aesculin, gelatin, starch and Tweens 20 and $60 . \mathrm{H}_{2} \mathrm{~S}$ and indole are not produced. Voges-Proskauer test is positive but the methyl red test is negative. Nitrate is reduced to nitrite, but nitrite is not reduced to nitrogen gas. Acid is produced from D-arabinose, D-glucose, Dfructose, D-mannose, D-mannitol, D-sorbitol and D-xylose, but not from D-adonitol, L-arabinose, cellobiose, glycerol, D-lactose, maltose, melezitose, melibiose, raffinose, Lrhamnose, salicin, L-sorbose, sucrose or trehalose. Sole carbon and energy sources are L-arabinose, cellobiose, Dfructose, D-galactose, D-glucose, glycerol, myo-inositol, D-mannitol, D-mannose, raffinose, L-rhamnose, D-ribose, D-sorbitol, sucrose, trehalose and D-xylose. The following substances are not used as sole sources of carbon or nitrogen: D-adonitol, dulcitol, D-fucose, inulin, D-lactose, maltose, melezitose, melibiose, salicin, adonitol, ethanol, acetate, benzoate, butyrate, citrate, formate, fumarate, Dgluconate, malate, malonate, pyruvate, suberate, succinate, L-alanine, L-arginine, L-asparagine, L-cysteine, L-cystine, Lglutamic acid, L-glutamine, L-glycine, L-histidine, hydroxyL-proline, L-isoleucine, L-leucine, L-lysine, L-methionine, Lornithine, L-phenylalanine, L-proline, L-serine, threonine, L-tryptophan and L-valine. With the API 50CH system, the following organic compounds are metabolized: D-arabinose, D-arabitol, D-glucose, D-fructose, D-mannose, inositol, D-mannitol, potassium 2-ketogluconate, potassium 5ketogluconate, D-sorbitol and D-xylose. The following substrates are oxidized in the Biolog GP system: D-arabitol, D-fructose, D-mannose, D-propionic acid, L-rhamnose, Dribose, D-sorbitol and Tweens 40 and 80. Constitutive expression of acid phosphatase, alkaline phosphatase, catalase, esterase (C4), esterase lipase (C8), leucine arylamidase, naphthol-AS-BI-phosphohydrolase and oxidase, but not $\alpha$-chymotrypsin, cystine arylamidase, $\alpha$ fucosidase, $\alpha$-galactosidase, $\beta$-galactosidase, $\alpha$-glucosidase, $\beta$-glucosidase, $N$-acetyl- $\beta$-glucosaminidase, $\beta$-glucuronidase, $\alpha$-mannosidase, trypsin, lipase (C14), urease or valine arylamidase. Cells are resistant to gentamicin $(10 \mu \mathrm{g})$, kanamycin $(30 \mu \mathrm{g})$, lincomycin $(2 \mu \mathrm{g})$, polymyxin $\mathrm{B}$ $(30 \mu \mathrm{g})$ and streptomycin $(10 \mu \mathrm{g})$, but susceptible to ampicillin $(30 \mu \mathrm{g})$, chloramphenicol $(30 \mu \mathrm{g})$, nalidixic acid $(20 \mu \mathrm{g})$, novobiocin $(30 \mu \mathrm{g})$, rifampicin $(5 \mu \mathrm{g})$ and tetracycline $(30 \mu \mathrm{g})$. The major amino acid constituents of the cell-wall hydrolysate are glycine and lysine. MK-6 is the predominant respiratory quinone $(69.2 \%$ in the type strain), with MK-7 (30.8\% in the type strain) present in minor amounts. The polar lipids consist of diphosphatidylglycerol, phosphatidylglycerol and one unknown phospholipid. The major cellular fatty acids are anteiso- $\mathrm{C}_{15: 0}$, anteiso- $\mathrm{C}_{17: 0}$ and iso- $\mathrm{C}_{15: 0}$. The $\mathrm{G}+\mathrm{C}$ content of the DNA of the type strain is $46.1 \mathrm{~mol} \%$.

The type strain, YIM-Y21 ${ }^{\mathrm{T}}$ (=CCTCC AA $207024^{\mathrm{T}}=$ DSM $19776^{\mathrm{T}}=$ KCTC $13192^{\mathrm{T}}$ ), was isolated from a brine sample collected from the Yipinglang salt mine in Yunnan, southwest China. 


\section{Acknowledgements}

This work was supported by grants from the National Natural Science Foundation of China (NSFC) (30860013, 30460004, 30660004, 30760006), Jishou University (jsdxkyzz200801, 07JDPHE148, 07JDPHE150, 07JDPHE151, 07JDPHE153), the Ministry of Science and Technology of China (863 Program; 2007AA021306, 2006BAE01A01-9) and the Yunnan Provincial Sciences and Technology Department (2005PY01-1, 2006C0006M) and Yunnan University (2008BY005). We are grateful to Ms Li-Xia Duan and Mr Huai-Dong Xiao and Ke Huang for their excellent technical assistance.

\section{References}

Amoozegar, M. A., Schumann, P., Hajighasemi, M., Ashengroph, M. \& Razavi, M. R. (2008). Salinicoccus iranensis sp. nov., a novel moderate halophile. Int J Syst Evol Microbiol 58, 178-183.

Aslam, Z., Lim, J. H., Im, W.-T., Yasir, M., Chung, Y. R. \& Lee, S.-T. (2007). Salinicoccus jeotgali sp. nov., isolated from jeotgal, a traditional Korean fermented seafood. Int J Syst Evol Microbiol 57, 633-638.

Chen, Y.-G., Cui, X.-L., Pukall, R., Li, H.-M., Yang, Y.-L., Xu, L.-H., Wen, M.-L., Peng, Q. \& Jiang, C.-L. (2007a). Salinicoccus kunmingensis sp. nov., a moderately halophilic bacterium isolated from a salt mine in Yunnan, south-west China. Int J Syst Evol Microbiol 57, 2327-2332.

Chen, Y.-G., Li, H.-M., Li, Q.-Y., Chen, W. \& Cui, X.-L. (2007b). Phylogenetic diversity of culturable bacteria in the ancient salt deposits of the Yipinglang Salt Mine, P. R. China. Wei Sheng Wu Xue Bao 47, 571-577 (in Chinese).

Collins, M. D. \& Jones, D. (1980). Lipids in the classification and identification of coryneform bacteria containing peptidoglycans based on 2,4-diaminobutyric acid. J Appl Bacteriol 48, 459-470.

Cowan, S. T. \& Steel, K. J. (1965). Manual for the Identification of Medical Bacteria. London: Cambridge University Press.

Cui, X.-L., Mao, P.-H., Zeng, M., Li, W.-J., Zhang, L.-P., Xu, L.-H. \& Jiang, C.-L. (2001). Streptomonospora salina gen. nov., sp. nov., a new member of the family Nocardiopsaceae. Int J Syst Evol Microbiol 51, 357-363.

Doetsch, R. N. (1981). Determinative methods of light microscopy. In Manual of Methods for General Bacteriology, pp. 21-33. Edited by P. Gerhardt, R. G. E. Murray, R. N. Costilow, E. W. Nester, W. A. Wood, N. R. Krieg \& G. H. Phillips. Washington, DC: American Society for Microbiology.

Felsenstein, J. (1981). Evolutionary trees from DNA sequences: a maximum likelihood approach. J Mol Evol 17, 368-376.

Felsenstein, J. (1985). Confidence limits on phylogenies: an approach using the bootstrap. Evolution 39, 783-791.

Felsenstein, J. (2002). PHYLIP (phylogeny inference package), version 3.6a. Distributed by the author. Department of Genome Sciences, University of Washington, Seattle, USA.

Franca, L., Rainey, F. A., Nobre, M. F. \& Costa, M. S. (2006). Salinicoccus salsiraiae sp. nov.: a new moderately halophilic grampositive bacterium isolated from salted skate. Extremophiles 10, 531536.

Gregersen, T. (1978). Rapid method for distinction of Gram-negative from Gram-positive bacteria. Eur J Appl Microbiol Biotechnol 5, 123127.

Groth, I., Schumann, P., Weiss, N., Martin, K. \& Rainey, F. A. (1996). Agrococcus jenensis gen. nov., sp. nov., a new genus of actinomycetes with diaminobutyric acid in the cell wall. Int J Syst Bacteriol 46, 234 239.
Hopwood, D. A., Bibb, M. J., Chater, K. F., Kieser, T., Bruton, C. J., Kieser, H. M., Lydiate, D. J., Smith, C. P. \& Ward, J. M. (1985). Preparation of chromosomal, plasmid and phage DNA. In Genetic Manipulation of Streptomyces - a Laboratory Manual, pp. 79-80. Edited by D. A. Hopwood, M. J. Bibb, K. F. Chater, T. Kieser, C. J. Bruton, H. M. Kieser, D. J. Lydiate, C. P. Smith, J. M. Ward \& H. Schrempf. Norwich: John Innes Foundation.

Hoyles, L., Collins, M. D., Foster, G., Falsen, E. \& Schumann, P. (2004). Jeotgalicoccus pinnipedialis sp. nov., from a southern elephant seal (Mirounga leonina). Int J Syst Evol Microbiol 54, 745-748.

Kimura, M. (1980). A simple method for estimating evolutionary rates of base substitutions through comparative studies of nucleotide sequences. J Mol Evol 16, 111-120.

Kluge, A. G. \& Farris, J. S. (1969). Quantitative phyletics and the evolution of anurans. Syst Zool 18, 1-32.

Kumar, S., Tamura, K. \& Nei, M. (2004). MEGA3: integrated software for molecular evolutionary genetics analysis and sequence alignment. Brief Bioinform 5, 150-163.

Lim, J.-M., Jeon, C. O., Song, S. M. \& Kim, C.-J. (2005). Pontibacillus chungwhensis gen. nov., sp. nov., a moderately halophilic Grampositive bacterium from a solar saltern in Korea. Int J Syst Evol Microbiol 55, 165-170.

Marquez, M. C., Ventosa, A. F. \& Berraquero, R. (1990). Marinococcus hispanicus, a new species of moderately halophilic Gram-positive cocci. Int J Syst Bacteriol 40, 165-169.

Mesbah, M., Premachandran, U. \& Whitman, W. B. (1989). Precise measurement of the $\mathrm{G}+\mathrm{C}$ content of deoxyribonucleic acid by highperformance liquid chromatography. Int J Syst Bacteriol 39, 159-167.

Minnikin, D. E., Collins, M. D. \& Goodfellow, M. (1979). Fatty acid and polar lipid composition in the classification of Cellulomonas, Oerskovia and related taxa. J Appl Bacteriol 47, 87-95.

Pakdeeto, A., Tanasupawat, S., Thawai, C., Moonmangmee, S., Kudo, T. \& Itoh, T. (2007). Salinicoccus siamensis sp. nov., isolated from fermented shrimp paste in Thailand. Int J Syst Evol Microbiol 57, 2004-2008

Saitou, N. \& Nei, M. (1987). The neighbor-joining method: a new method for reconstructing phylogenetic trees. Mol Biol Evol 4, 406425 .

Sasser, M. (1990). Identification of bacteria by gas chromatography of cellular fatty acids, MIDI Technical Note 101. Newark, DE: MIDI Inc.

Schleifer, K. H. (1985). Analysis of the chemical composition and primary structure of murein. Methods Microbiol 18, 123-156.

Shirling, E. B. \& Gottlieb, D. (1966). Methods for characterization of Streptomyces species. Int J Syst Bacteriol 16, 313-340.

Smibert, R. M. \& Krieg, N. R. (1994). Phenotypic characterization. In Methods for General and Molecular Bacteriology, pp. 607-654. Edited by P. Gerhardt, R. G. E. Murray, W. A. Wood \& N. R. Krieg. Washington, DC: American Society for Microbiology.

Staneck, J. L. \& Roberts, G. D. (1974). Simplified approach to identification of aerobic actinomycetes by thin-layer chromatography. Appl Microbiol 28, 226-231.

Thompson, J. D., Gibson, T. J., Plewniak, F., Jeanmougin, F. \& Higgins, D. G. (1997). The CLUSTAL_X windows interface: flexible strategies for multiple sequence alignment aided by quality analysis tools. Nucleic Acids Res 25, 4876-4882.

Ventosa, A., Quesada, E., Rodriguez-Valera, F., Ruiz-Berraquero, F. \& Ramos-Cormenzana, A. (1982). Numerical taxonomy of moderately halophilic Gram-negative rods. J Gen Microbiol 128, 1959-1968.

Ventosa, A., Marquez, M. C., Ruiz-Berraquero, F. \& Kocur, M. (1990). Salinicoccus roseus gen. nov., sp. nov., a new moderately halophilic Gram-positive coccus. Syst Appl Microbiol 13, 29-33. 
Ventosa, A., Marquez, M. C., Weiss, N. \& Tindall, B. J. (1992). Transfer of Marinococcus hispanicus to the genus Salinicoccus as Salinicoccus hispanicus comb. nov. Syst Appl Microbiol 15, 530-534.

Yoon, J.-H., Lee, K.-C., Weiss, N., Kang, K. H. \& Park, Y.-H. (2003).

Jeotgalicoccus halotolerans gen. nov., sp. nov. and Jeotgalicoccus psychrophilus sp. nov., isolated from the traditional Korean fermented seafood jeotgal. Int J Syst Evol Microbiol 53, 595-602.
Zhang, W., Xue, Y., Ma, Y., Zhou, P., Ventosa, A. \& Grant, W. D. (2002). Salinicoccus alkaliphilus sp. nov., a novel alkaliphile and moderate halophile from Baer Soda Lake in Inner Mongolia Autonomous Region, China. Int J Syst Evol Microbiol 52, 789-793.

Zhang, Y.-Q., Yu, L.-Y., Liu, H.-Y., Zhang, Y.-O., Xu, L.-H. \& Li, W.-J. (2007). Salinicoccus luteus sp. nov., isolated from a desert soil. Int J Syst Evol Microbiol 57, 1901-1905. 